\title{
Financial Development, Trade Openness and Economic Growth: A Trilateral Analysis of Bahrain
}

\author{
Hatem Hatef Abdulkadhim Altaee ${ }^{1} \&$ Mohamed Khaled Al-Jafari ${ }^{2}$ \\ ${ }^{1}$ Department of Accounting, Cihan University, Sulaimaniyah-Kurdistan Region, Iraq \\ ${ }^{2}$ Department of Accounting and Finance, College of Business Administration, Prince Mohammad Bin Fahd \\ University, Al Khobar, Kingdom of Saudi Arabia \\ Correspondence: Mohamed Khaled Al-Jafari, Department of Accounting and Finance, College of Business \\ Administration, Prince Mohammad Bin Fahd University, P. O. Box 1664, Al Khobar 31952, Kingdom of Saudi \\ Arabia. Tel: 966-53-005-2740. E-mail: aljafarimohamedkhaled@yahoo.com
}

Received: October 23, 2014

doi:10.5539/ijef.v7n1p241

\begin{abstract}
This study investigates the relationship between trade openness, financial development and economic growth for the Kingdom of Bahrain. Time series data are utilized form 1980 till 2012. The vector error correction model (VECM) in combination with innovation of accounting (variance decomposition and impulse response function) analysis are employed to explore the causal relationship between the variables. The stationarity properties of the data and the order of integration are tested using both the Augmented Dickey-Fuller (ADF) test and the Phillips-Perron (PP) test. All variables are found to be cointegrated indicating the existence of long-run relationship. The empirical findings show that trade openness and financial development have causal impact on economic growth. Conversely, growth is found to have no causal impact on trade and financial development, implying support for "trade-led growth" and "finance-led growth" hypotheses. Furthermore, the results show a short-run causality from financial development to trade openness. The findings suggest that trade openness and financial development are important elements in determining economic growth in Bahrain. Therefore, Bahrain should continue to patronize the development of its financial sector and to allow more trade openness in order to achieve a high and sustainable economic growth.
\end{abstract}

Keywords: Augmented Dickey-Fuller test, economic growth, financial development, impulse response function, Kingdom of Bahrain, Phillips-Perron test, trade openness, variance decomposition, VECM

\section{Introduction}

Bahrain has a long history of openness. It is the most diversified economy in the Gulf Cooperation Council (GCC) region. It is the freest economy in the Arab World and ranked among the twelve most open economy worldwide by the Heritage Foundation and the Wall Street Journal 2013, Index of Economic Freedom.

The Kingdom boasts of its economic freedom, openness and diversity. In 2012, the oil and gas sector contributed $19 \%$ of the real GDP compared to $44 \%$ in 2000 reflecting the relatively small change in oil and gas volumes. It has a long history of dependency on trade and it is considered the most diversified economy among the Gulf Cooperation Council (GCC) countries. Bahrain implemented a Free Trade Agreement (FTA) with the US in August 2006, the first FTA between the US and a member state of the GCC countries. It succeed to achieve that by maintaining a safe investing environment and adopting a policy of open markets as an economic development tool. It has a tax free business environment, no exchange control, and 100\% foreign ownership permitted in all activities. This, in turn, has engendered a culture of economic openness.

Like other GCC countries, the primary focus of policies in Bahrain is to obtain high and sustainable growth. GDP in constant prices in Bahrain averaged 7,050 BHD Million in 2000 and reaching an all-time high of 10,771 BHD Million in 2013. Bahrain has recorded a real GDP growth rate of 5.7\% over the last five years (EIU, 2011). However, to achieve and maintain a higher growth rate, policy makers need to determine the most factors behind this high growth.

The impact of financial development on economic growth in both developed and developing countries has been well studied in the empirical literature (Levine, 1997, 2005; Beck, 2011, 2013; Pasali, 2013; Panizza, 2013). 
Generally, a positive effect of financial development on economic growth is found in the most of these studies.

According to Levine (2005) there are four main mechanisms through which finance can promote economic growth: First, the pooling of savings through risk diversification and risk management; second, the facilitation of exchange through the reduction of transaction costs; Third, the improvement of capital allocation through the production of ex-ante information about investment opportunities; and fourth, the increase of investors' willingness to finance new projects through ex-post monitoring and corporate governance.

Most recent studies suggested that financial development would have a substantial positive impact on economic growth (Goldsmith, 1969; King \& Levine, 1993a, 1993b; Levine \& Zervos, 1998; Levine, 1997; Beck, Levine, \& Loayza, 2000; Beck et al., 2008; Rousseau \& Wachtel, 1998; Rajan \& Zingales, 1998; Özyildirim \& Önder, 2008; Michalopoulos, Laeven, \& Levine, 2009; Oguzoglu \& Stengos, 2011; Dabos \& Williams, 2009; Aghion, Howitt, \& Mayer-Foulkes, 2005; Pradhan, 2011; Masoud \& Hardaker, 2012; among others).

The argument in favor of trade openness goes back to early work of famous British economist Adam Smith in his idea about market specialization. It finds support for the endogenous growth theory associated with Romer (1986, 1990); Lucas (1988); Rebelo (1991); Rivera-Batiz and Romer (1991); Grossman and Helpman (1991a, 1991b); and Grossman (1992). The benefits from trade liberalization might be realized through: First, openness promotes the efficient allocation of resources; second, allows the dissemination of knowledge and technological advancement; third, stimulates competition in domestic and international markets; and fourth, increases returns to scale.

Empirical evidence supports this hypothesis is quite abundant (Grossman \& Helpman, 1991b; Young, 1991; Dollar, 1992; Lee, 1993; Wacziarg, 1998; Eicher, 1999; Dollar \& Kraay, 2001; Srinivasan \& Bhagwati, 2001; Jin, 2003; Utkulu \& Kahyaoğlu, 2005; Yaprakli, 2007; Kurt \& Berber, 2008; Omisakin, Oluwatosin, \& Ayoola, 2009; Ehinomen \& Da'silva1, 2014; among others).

However, this empirical evidence continues to be questioned for at least two main reasons: First, there are still some discussions and doubts on the way countries' trade openness is measured. Second, the debate on the utilized econometrical methods is still open (Dollar \& Kraay, 2004; Loayza, Fajnzylber \& Calderon, 2005; Harrison, 1996; Rodríguez \& Rodrik, 1999).

This paper is organized into five sections as follows: Section two displays the literature review while, data and specifications of the multivariate (VAR) model are described in section three. This section also includes other tests such as stationarity test, cointegration test, Granger causality test and variance decomposition (VD) and impulse response function (IRF) analysis. The empirical results and findings are presented and analyzed in section four. Finally, section five summarizes the paper and presents the concluding remarks.

\section{Literature Review}

Trade openness, financial development, and economic growth are usually examined in the empirical literature in two different approaches: The first one tries to investigate the impact of trade openness or financial development on economic growth individually. On the other hand, the second approach examines the relationship between trade liberalization and the financial development jointly. With respect to methods utilized to assess the impact of financial development and (or) trade openness on economic growth, there are two main econometrical methods. The first technique utilizes simple or multiple regression, while the second method employs the causality issue in a bivariate model. However, most recent studies have tended to focus on VAR and VEC models and cointegration approach.

For example, Yazdi and Shakouri (2014) investigate the long-run cointegrating and short-run dynamic relationship among carbon emissions, energy consumption, economic growth, urbanization, financial development and openness to trade in Iran by using autoregressive distributed lag (ARDL) testing approach of cointegration. The direction of causal relationship between the series is examined by employing VECM Granger causality approach. The empirical results suggest an evidence of long-run relationship between the variables in Iran.

Similarly, Islam, Shahbaz and Rahman (2014) implement the ARDL bounds testing and the Johansen-Juselius (JJ) approach to cointegration to explore the long-run relationship among energy use, economic growth, financial development, capital, and trade openness in Australia. They also apply the vector error correction model (VECM) to understand the short-run dynamics. The study covers the period from 1965 until 2009 and is hallmarked by major shocks across the globe which can potentially cause structural break in the series. The Granger causality test shows bidirectional causality between energy consumption and economic growth; financial development and energy consumption; trade openness and economic growth; economic growth and financial development; energy 
consumption and trade openness; and finally financial development and trade openness.

On the other hand, Polat, Ijaz, Rehman and Satti (2013) revisit the impact of financial development on economic growth in South Africa by incorporating trade openness in the production function. The study covers the period of 1970-2011 and apply the Bayer-Hanck combined cointegration approach to examine the long-run relationship between the variables. The findings indicate that financial development stimulates economic growth. Capital use contributes to economic growth but trade openness impedes economic growth. The demand-side hypothesis is validated in South Africa.

In Indonesia, Shahbaz, Hye, Tiwari and Leitão (2013) examine the linkages among economic growth, energy consumption, financial development, trade openness and CO2 emissions over the period of 1975Q1-2011Q4. The stationarity analysis is performed by using Zivot-Andrews unit root test and the ARDL bounds testing approach for long-run relationship between the series in the presence of structural breaks. The causality between the concerned variables is examined by the VECM Granger causality technique and robustness of causal analysis is tested by innovative accounting approach (IAA). The results confirm that variables are cointegrated. This means that the long-run relationship exists in the presence of structural breaks. Also, the empirical findings indicate that economic growth and energy consumption increase $\mathrm{CO} 2$ emissions, while financial development and trade openness compact it. The VECM causality analysis supported the feedback hypothesis between energy consumption and $\mathrm{CO} 2$ emissions. Economic growth and $\mathrm{CO} 2$ emissions are also interrelated, and financial development Granger causes $\mathrm{CO} 2$ emissions.

As for China, Shahbaz, Khan and Tahir (2013) investigate the relationship between energy use and economic growth by incorporating financial development, international trade and capital as important factors of production function for the period of 1971-2011. The ARDL bounds testing approach to cointegration was applied to examine the long-run relationship among the series. However, the stationarity properties of the variables were tested by using structural break test. The empirical evidence confirmed a long-run relationship among the variables. The results showed that energy use, financial development, capital, exports, imports and international trade have positive impact on economic growth.

On the other hand, Tash and Sheidaei (2012) analyze the joint impact of trade liberalization and financial development on economic growth in Iran, using endogenous growth theory during the period 1966-2010. In this paper, the principal component analysis is applied to make better indexes for trade liberalization, financial development and the joint effect of both. The empirical findings obtained from Johansen cointegration procedure signify a positive relationship between trade liberalization, financial development and the joint impact on economic growth in Iran.

Moving to Nigeria, Chimobi (2010) examines the causal relationship among financial development, trade openness and economic growth from 1970 until 2005. The findings reveal that trade openness and financial development have a causal impact on economic growth. On the other hand, growth found to have a causal impact on trade and financial development, implying support for growth-led trade and no support for trade-led growth.

In Turkey, Kar, Peker and Kaplan (2008) try to empirically estimate the joint impact of trade liberalization and financial development on economic growth. Instead of using common proxies for the issue, the principal components analysis is employed to develop better measures (indexes) for trade liberalization, financial development and the joint effect of both. The empirical results obtained from the Johansen cointegration procedure show that trade liberalization, financial development and the joint impact of both positively contributed to economic growth for the period 1963-2005.

On the other hand, Liang and Teng (2006) investigate the relationship between financial development and economic growth in China from 1952 until 2001. After considering the time series characteristics of the dataset, a multivariate vector autoregressive (VAR) framework is used as an appropriate specification and the long-run relationship among financial development, growth and other key growth factors is analyzed in a theoretically based high dimensional system by identification of cointegrating vectors through tests of over-identifying restrictions. The empirical results suggest existence of a unidirectional causality from economic growth to financial development. This conclusion departs distinctively from those in the previous studies.

\section{Data and Methodology}

This study covers the period from 1980 till 2012. All necessary data for the sample period are obtained from World Development Indicators (2014) provided by the World Bank. Trade openness is measured by the ratio of the sum of imports and exports over GDP (denoted TOP). This ratio has been considered as the most simple and popular 
indicator of trade openness. The standard measure of financial development is the ratio of M2 to GDP, the World Bank (1989). However, this ratio measures the extent of monetization rather than financial development. In developing countries, monetization can be increasing without financial development; therefore, M2/GDP is not a satisfactory indicator of financial development. Accordingly, the ratio of total bank deposit liabilities to GDP is a better proxy of measurement of financial development, Khan and Qayyum (2007). Similarly, we utilized the ratio of domestic credit divided by GDP as a proxy of financial development. On the other hand, the growth rate of real gross domestic product is used as an indicator of economic growth (denoted GDP). All variables are measured in 2005 constant local prices, and used in their natural logarithmic form.

\subsection{Model Specification}

The primary model showing the causal relationship among financial development, trade openness and economic growth in Bahrain can be written as:

$$
G D P_{t}=f\left(T O P_{t}, F D_{t}\right)
$$

The function can also be represented in a log-linear econometric format thus:

$$
\ln \left(G D P_{t}\right)=\beta_{0}+\beta_{1} \ln \left(T O P_{t}\right)+\beta_{2} \ln \left(F D_{t}\right)+\varepsilon_{t}
$$

Where:

GDP: is growth rate of Gross Domestic Product.

FD: financial development (measured as domestic credit divided by GDP).

TOP: is Trade Openness equal to sum of import and export to GDP, $(E X+I M) / G D P$.

$\beta_{0}$ : is the constant term, ' $\mathrm{t}$ ' is the time trend, and ' $\varepsilon$ ' is the random error term.

Our methodological framework consists of two approaches: The first approach is the traditional Engle-Granger in VECM framework, while the second approach is the forecast error variance decomposition.

We will also conduct series of diagnostic tests to confirm the standard properties of VECM model vis., residuals autocorrelation, heteroskedasticity, normality, and to check if any lag is excluded from the model for the studied variables. Performing these tests will validate the further analysis of the results obtained by the model. But before all of these, the descriptive statistics of the three series will be presented.

The traditional Granger causality test based on standard VAR is conditional on the assumption of stationarity of the data series variables included in the VAR model. If the time series is non-stationary, the stability condition of model is not met, and thus the Wald $\chi^{2}$ test statistic for Granger-causality becomes meaningful. In such situation cointegration and vector error correction model (VECM) are more appropriate to investigate the relationship between non-stationary time series. Therefore, our investigation begins by examining the stationarity properties of the variables, followed by cointegration analysis and Granger causality tests in a trivariate framework.

\subsection{The Stationarity Test}

To proceed for Granger causality analysis, we have to test for stationary properties of our series. However, nonstationarity is a property common to many macroeconomic and financial time series. It means that a variable has no clear tendency to return to a constant value or a linear trend. We have carried out unit root analysis by applying two different tests: the Augmented Dickey-Fuller (hereafter, ADF) (1981) test, and the Phillips-Perron (hereafter, PP) (1988) test. Using PP test is necessitated by the idea that ADF test can over-reject the null hypothesis when it is true and under reject it when it is false (DeJong, Nankervi, \& Savin, 1992; Harris \& Sollis, 2003). Moreover, PP test is adjusted to take into account serial correlation.

\subsection{Testing for Cointegration}

After testing the stationarity of the time series and having the same order of integration, we test the presence of cointegration between the time series of the same order of integration through forming a cointegration equation. Cointegration is the statistical analog commonly used to exam the existence of long-run relations between one or more time series. The basic idea behind cointegration is that if in the long-run two or more time series variables move closely together, even though the series themselves are trended, the difference between them is constant. It is possible to regard these variables as defining a long-run equilibrium relationship, as the difference between them is stationary (Hall \& Henry, 1989). On the other hand, the absence of cointegration implies that there is no long-run relationship between the variables. Since all tested variables are integrated of order of one i.e., $I(1)$, the cointegration hypothesis between the variables is examined by the Johansen and Juselius (1990) cointegration test. Moreover, this test is robust to various departures from normality. It allows any of the variables in the model to be used as dependent variable while maintaining the same cointegrating results. Both the Trace $\lambda_{\text {trace }}$ and 
maximum Eigenvalue $\lambda_{\max }$ tests were used under the null hypothesis of no cointegrating vector. For both tests, if the test statistic value is greater than the critical value, the null hypothesis of $r$ cointegrating vectors is rejected in favor of the corresponding alternative hypothesis.

Since it is well-known that the cointegration tests are very sensitive to the choice of lag length, the relevant order of lag of the vector autoregression (VAR) model should be specified before undertaking cointegration test.

\subsection{Granger Causality Test}

After determining the orders of integration of the variables and finding cointegration among financial development (FD), trade openness (OP), and economic growth (GDP), the Engle-Granger causality test is carried out in framework of VECM. The vector error correction model is designed to determine whether cointegration exists between two variables. In order for this to be true, there must be a Granger causality in at least one direction, but the most valuable aspect is that cointegration does not reflect the direction of the causality between the variables. In a VECM, long and short-run parameters are separated. The error correction version pertaining to the three variables incorporated in this study is stated below:

$$
\begin{gathered}
{\left[\begin{array}{c}
\Delta \ln G D P_{t} \\
\Delta \ln F D_{t} \\
\Delta \ln T O P_{t}
\end{array}\right]=\left[\begin{array}{l}
\alpha_{1} \\
\alpha_{2} \\
\alpha_{3}
\end{array}\right]+\left[\begin{array}{l}
\beta_{11,1} \beta_{12,1} \beta_{13,1} \\
\beta_{21.1} \beta_{22,1} \beta_{23,1} \\
\beta_{31,1} \beta_{32,1} \beta_{33,1}
\end{array}\right]\left[\begin{array}{c}
\Delta \ln G D P_{t-1} \\
\Delta \ln F D_{t-1} \\
\Delta \ln T O P_{t-1}
\end{array}\right]+\left[\begin{array}{c}
\beta_{11,2} \beta_{12,2} \beta_{13,2} \\
\beta_{21,2} \beta_{22,2} \beta_{23,2} \\
\beta_{31,2} \beta_{32,2} \beta_{33,2}
\end{array}\right]\left[\begin{array}{c}
\Delta \ln G D P_{t-2} \\
\Delta \ln F D_{t-2} \\
\Delta \ln T O P_{t-2}
\end{array}\right]} \\
+\left[\begin{array}{c}
\beta_{11,3} \beta_{12,3} \beta_{13,3} \\
\beta_{21.3} \beta_{22,3} \beta_{23,3} \\
\beta_{31,3} \beta_{32,3} \beta_{33,3}
\end{array}\right]\left[\begin{array}{c}
\Delta \ln G D P_{t-3} \\
\Delta \ln F D_{t-3} \\
\Delta \ln T O P_{t-3}
\end{array}\right]+\ldots+\left[\begin{array}{c}
\beta_{11, p} \beta_{12, p} \beta_{13, p} \\
\beta_{21 . p} \beta_{22, p} \beta_{23, p} \\
\beta_{31, p} \beta_{32, p} \beta_{33, p}
\end{array}\right]\left[\begin{array}{c}
\Delta \ln G D P_{t-p} \\
\Delta \ln F D_{t-p} \\
\Delta \ln T O P_{t-p}
\end{array}\right]+\left[\begin{array}{l}
\gamma_{1} \\
\gamma_{2} \\
\gamma_{3}
\end{array}\right]\left[E C T_{t-1}\right]+\left[\begin{array}{l}
\varepsilon_{1 t} \\
\varepsilon_{2 t} \\
\varepsilon_{3 t}
\end{array}\right]
\end{gathered}
$$

Where $\left[E C T_{t-1}\right]$ is the error correct term derived from the long-run cointegration relationship and is equivalent to $\left(\varepsilon_{t}=G D P_{t}-\alpha-\beta G D P_{t}\right)$. The coefficient of the $\mathrm{ECT}_{t-1}$ variable contains information about whether past values of variables affect the current values. The size and statistical significance of the coefficient of the error correction term in each ECM model measures the tendencies of each variable to return to the equilibrium. A significant coefficient implies that past equilibrium errors plays a role in determining current outcomes.

In the ECM (3) above, Granger causality can be examined in three ways:

1) By testing the significance of the lagged differences of the variables in the above mentioned equation through a joint Wald or F-test; this is a measure of short-run (or weak Granger) causality.

2) By observing the significance of the error-correction term in the above equation as a measure of long-run causality; the t-statistic of coefficients $\gamma_{1}, \gamma_{2}$ and $\gamma_{3}$ is sufficient for this purpose.

3) By reviewing the joint significance of the error-correction term and the lagged variables in each VEC variable through a joint Wald or F-test, sometimes mentioned as a measure of 'strong Granger causality' (Oh \& Lee, 2004).

The final step we will perform is a diagnostic check for the stochastic properties of the VECM. This would justify the validity of the model assumption, then further analysis based on the model would be possible and the inferences drawn from the VECM would be unbiased. Table 1 below summarizes the different proprieties to be tested and the employed test.

Table 1. Diagnostic checking

\begin{tabular}{ll}
\hline Stochastic Property & Test \\
\hline Autocorrelation & Lagrange Multiplier (LM) \\
Heteroskedasticity & White heteroskedasticity \\
Normality of residuals, & Residual Covariance (Urzua) \\
possibility of lag exclusion & Wald lag exclusion \\
Stability of VECM & Autoregressive (AR) polynomial \\
\hline
\end{tabular}

\subsection{Variance Decomposition and Impulse Response Function Analysis}

The causality analysis cannot capture the relative strength of causal relation between the variable beyond the selected time period. This weakens the reliability of causality results by the VECM. To overcome this problem, the forecast error variance decomposition (VD) and impulse response function (IRF) are employed. The variance 
decomposition show how much a given variable changes under the impact of its own shock and the shock of other variables. Therefore, the variance decomposition defines the relative importance of each random innovation in affecting the variables in the VAR. The variance decomposition approach indicates the magnitude of the predicted error variance for a series accounted for by innovation from each of the independent variables over different time-horizons beyond the selected time period (Enders, 2003). The IRF traces out the responsiveness of endogenous variable in VAR to shocks to each of the other exogenous variables over a certain period of time. There are different ways of performing IRFs, however, a generalized approach has been preferred over Choleskey orthogonalization approach or other orthogonalization approaches, due to the invariant of ordering of the variables (Tiwari, 2011).

\section{The Empirical Results}

This section presents the empirical findings with a thorough analysis of the results. Unit root test results are reported first followed by Johansen cointegration test results. Finally, Granger-causality test results in static framework (using VECM) and dynamic framework (using IRF and VD) are presented and analyzed.

\subsection{Unit Root Test}

The first step is to test whether the variables of our interest are stationary and to determine their orders of integration. The results of both the ADF and PP tests are reported in Table 2. The findings indicate that real GDP, trade openness and financial development are not stationary in their level. However, at first difference, all series become stationery indicating that all variables are integrated of order one $I(1)$.

Table 2. Unit root tests

\begin{tabular}{cccccc}
\hline \multirow{2}{*}{ Variables } & & & \multicolumn{2}{c}{ Unit Root Tests } \\
\cline { 5 - 6 } & Constant & Constant \& Trend & ADF & PP \\
\hline LGDP & $\sqrt{ }$ & & -1.179 & -1.322 \\
D(LGDP) & $\sqrt{ }$ & & $-4.577^{*}$ & $-4.577^{*}$ \\
FD & & $\sqrt{ }$ & -2.801 & -3.449 \\
D(FD) & & $\sqrt{ }$ & $-4.814^{*}$ & $-12.138^{*}$ \\
LTOP & & $\sqrt{ }$ & -3.069 & -2.961 \\
D(LTOP) & $\sqrt{ }$ & & $-6.578^{*}$ & $-6.602^{*}$ \\
\hline
\end{tabular}

Notes.* Significant at $1 \%$ level.

\subsection{Cointegration Results}

Table 3. Results of Johansen's maximum likelihood tests for multiple cointegrating relationships

\begin{tabular}{|c|c|c|c|c|}
\hline \multicolumn{5}{|c|}{ Unrestricted Cointegration Rank Test (Trace) } \\
\hline Hypothesized & & Trace & 0.05 & \\
\hline No. of CE(s) & Eigenvalue & Statistic & Critical Value & Prob.** \\
\hline None * & 0.624465 & 53.49810 & 42.91525 & 0.0032 \\
\hline At most 1 & 0.450416 & 23.13663 & 25.87211 & 0.1055 \\
\hline At most 2 & 0.137352 & 4.580207 & 12.51798 & 0.6573 \\
\hline \multicolumn{5}{|c|}{ Unrestricted Cointegration Rank Test (Maximum Eigenvalue) } \\
\hline Hypothesized & & Max-Eigen & 0.05 & \\
\hline No. of $\mathrm{CE}(\mathrm{s})$ & Eigenvalue & Statistic & Critical Value & Prob. ${ }^{* *}$ \\
\hline None * & 0.624465 & 30.36147 & 25.82321 & 0.0117 \\
\hline At most 1 & 0.450416 & 18.55642 & 19.38704 & 0.0657 \\
\hline At most 2 & 0.137352 & 4.580207 & 12.51798 & 0.6573 \\
\hline
\end{tabular}

Note. Max-eigenvalue test indicates 1 cointegrating eqn(s) at the 0.05 level. $*$ denotes rejection of the hypothesis at the 0.05 level.

**MacKinnon-Haug-Michelis (1999) p-values.

After confirming the stationarity of the variables at $I(1)$, we proceed to examine the issue of cointegration among the variables. When a cointegration relationship is present, it means that financial development, trade openness and economic growth share a common trend and long-run equilibrium. We started the cointegration analysis 
under the null hypothesis of no cointegrating vector, by employing the Johansen and Juselius multivariate cointegration test.

Table 3 shows that both Trace and Eigenvalue criteria indicate a long-run equilibrium relationship between the variables at the 5\% level. We can reject the null hypothesis of non-cointegrating vector against the alternative of at most one cointegrating vector. In other words, there are a long-run relationships among the variables and there are a nexus among financial development, trade openness and economic growth for Bahrain economy.

Since, it is well known that the cointegration tests are vary to the choice of lag length. The relevant order of lag of the vector autoregression (VAR) model should be specified before undertaking cointegration test. The results of LR, SC and HQ indicate that the optimal lag order is 1 as shown in Table 4.

Table 4. Lag order selection criterion

\begin{tabular}{ccccccc}
\hline Lag & Log L & LR & FPE & AIC & SC & HQ \\
\hline 0 & 46.59093 & NA & $8.92 \mathrm{e}-06$ & -3.113638 & -2.970902 & -3.070002 \\
1 & 115.9234 & $118.8557^{*}$ & $1.21 \mathrm{e}-07$ & -7.423102 & $-6.852157^{*}$ & $-7.248558^{*}$ \\
2 & 125.4268 & 14.25512 & $1.19 \mathrm{e}-07^{*}$ & -7.459060 & -6.459906 & -7.153609 \\
3 & 133.0216 & 9.764725 & $1.41 \mathrm{e}-07$ & -7.358687 & -5.931325 & -6.922329 \\
4 & 142.6854 & 10.35400 & $1.54 \mathrm{e}-07$ & -7.406097 & -5.550526 & -6.838830 \\
5 & 154.5021 & 10.12865 & $1.59 \mathrm{e}-07$ & $-7.607294^{*}$ & -5.323515 & -6.909120 \\
\hline
\end{tabular}

Note. ${ }^{*}$ indicates lag order selected by the criterion.

\subsection{The Short and Long-Run Causality Analysis}

Having found cointegrating relationship between GDP, FD, and TOP, Granger-causality analysis is carried out next and the results are reported in Table 5. Regarding the upper part of the Table, the first column defines the dependent variables; second to fourth columns display Wald $\chi^{2}$ statistics for the joint significance of each of the other lagged endogenous variables.

Table 5. VECM Engle-Granger causality analysis

\begin{tabular}{|c|c|c|c|}
\hline \multicolumn{4}{|c|}{ VEC Granger Causality Short-Run (Wald Test $/ \chi^{2}$ ) } \\
\hline & $\mathrm{D}(\ln (\mathrm{GDP}))$ & $\mathrm{D}(\ln (\mathrm{TOP}))$ & $\mathrm{D}(\ln (\mathrm{FD}))$ \\
\hline $\mathrm{D}(\operatorname{Ln}(\mathrm{GDP}))$ & - & 1.191 & 0.891 \\
\hline $\mathrm{D}(\operatorname{Ln}(\mathrm{TOP}))$ & $8.359^{*}$ & - & 1.052 \\
\hline $\mathrm{D}(\operatorname{Ln}(\mathrm{FD}))$ & $18.925 *$ & $3.381 * * *$ & - \\
\hline \multicolumn{4}{|c|}{ VEC Granger Causality Long Run } \\
\hline CointEq1 & $-0.046^{* *}$ & $-0.022 * *$ & $-0.089 * *$ \\
\hline & -0.016 & $(0.0 .33)$ & -0.028 \\
\hline
\end{tabular}

Note. (1) $* * *$ and $* * *$ denote rejection of the corresponding non-causality hypothesis at $1 \%$ and $5 \%$ and $10 \%$ level respectively. (2) In parentheses are the standard error of the parameters.

Granger-causality results based on VECM reported in Table 5 suggest that the null hypothesis that TOP does not Granger causes GDP is rejected at $1 \%$ significant level, which indicates the presence of causality from TOP to GDP. This result goes in line with the hypothesis which states that more outward-oriented countries register higher economic growth (Sachs \& Warner, 1995; Edwards, 1998; Frankel \& Romer, 1999; Dollar \& Kraay, 2004; Lee, Ricci \& Rigobon, 2004; Foster, 2008; Yavari \& Mohseni, 2012).

We also find a positive and significant impact of FD on real GDP. This result is in accordance with the prediction that financial development is a necessary condition for achieving a high rate of economic growth (GDP), and has a strong positive relationship with economic growth (Kletzer \& Bardhan, 1987; Bencivenga \& Smith, 1991; Bencivenga, Smith, \& Starr, 1995; Benhabib \& Spiegel, 2000; Amable \& Chatelain, 2001; Xiaohui \& Chang, 2002; Shan \& Morris, 2002; Calderon \& Liu, 2003; Onayemi, 2013).

As for financial development and trade openness, the study found a positive and significant impact of FD on TOP. GDP Granger does not cause financial development, thus, the hypothesis is not rejected.

The coefficients of the ECT in all equations have the desirable sign and statically significant at the 5\% 
significant level. It is worth noting that the speed of TOP toward adjustment is slow relative to that of GDP and FD. The significant coefficients of the error correction terms for each time series indicate that they all cause one another in the long-run.

\subsection{The Stability of VECM}

The Stability of the estimated VECM is examined by checking the roots of characteristic polynomial, which is reported in Table 6 . According to this table, all roots are less than unity and lie within the unit circle. Accordingly, the estimated models are stable or stationary. This is a very favorable result because if VAR were not stable, certain results such as impulse response standard errors would not be valid, making the model results and conclusions to be dubious.

Table 6. VECM stability analysis

\begin{tabular}{ll}
\hline Root & Modulus \\
\hline 1.000000 & 1.000000 \\
1.000000 & 1.000000 \\
0.634356 & 0.634356 \\
$0.013865-0.462813 \mathrm{i}$ & 0.463020 \\
$0.013865+0.462813 \mathrm{i}$ & 0.463020 \\
-0.330979 & 0.330979 \\
\hline
\end{tabular}

Note. VEC specification imposes 2 unit root(s).

Results of the diagnostic tests of VECM are reported in Table 7.

Table 7. Diagnostic checks analysis

\begin{tabular}{|c|c|c|}
\hline \multicolumn{3}{|c|}{ VEC Lag Exclusion Wald Tests } \\
\hline & $\left(\chi^{2}\right.$ Test Statistics for Lag Exclusion) for DLag3 (Joint Test) & p-value \\
\hline & 45.78 & 0.000 \\
\hline \multicolumn{3}{|c|}{ VEC Residual Serial Correlation } \\
\hline Dlag1 & 13.406 & 0.145 \\
\hline Dlag2 & 12.227 & 0.201 \\
\hline Dlag3 & 9.448 & 0.397 \\
\hline \multicolumn{3}{|c|}{ VEC Residual Normality Tests Orthogonalization: Residual Covariance (Urzua) } \\
\hline & 25.18 & 0.452 \\
\hline \multicolumn{3}{|c|}{ VEC Residual Heteroskedasticity Tests: No Cross Terms (only levels and squares) } \\
\hline & 18.946 & 0.78 \\
\hline
\end{tabular}

It is evidence from the figures in the table that models are free from autocorrelation problem. The White's heteroscedasticity test indicates the validity of homoscedasticity assumption. The residual normality test indicates the normality of the residual assumption. Based on the above tests, we can conclude that VECM is correctly specified and has performed well and therefore, it is stable. These results permit us to go a step further and perform causality analysis.

\subsection{The Results of the IRF and VD}

The results of the impulse response function (IRF) are reported in Figure 1. As demonstrated in the diagram, economic growth responds negatively due to one standard deviation in trade openness, and up to the 10th time horizon. The results also indicate that response in financial development due to forecast error stemming in trade openness is initially negative, then it turns out to be positive between the 2 nd and the 4 th time horizon and negative afterward. 


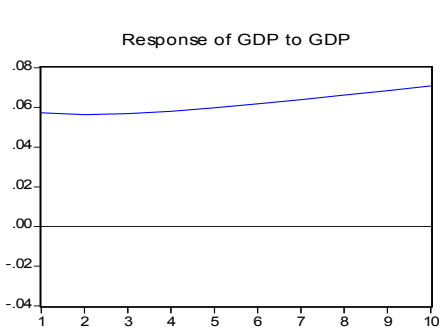

Response to Generalized One S.D. Innovations
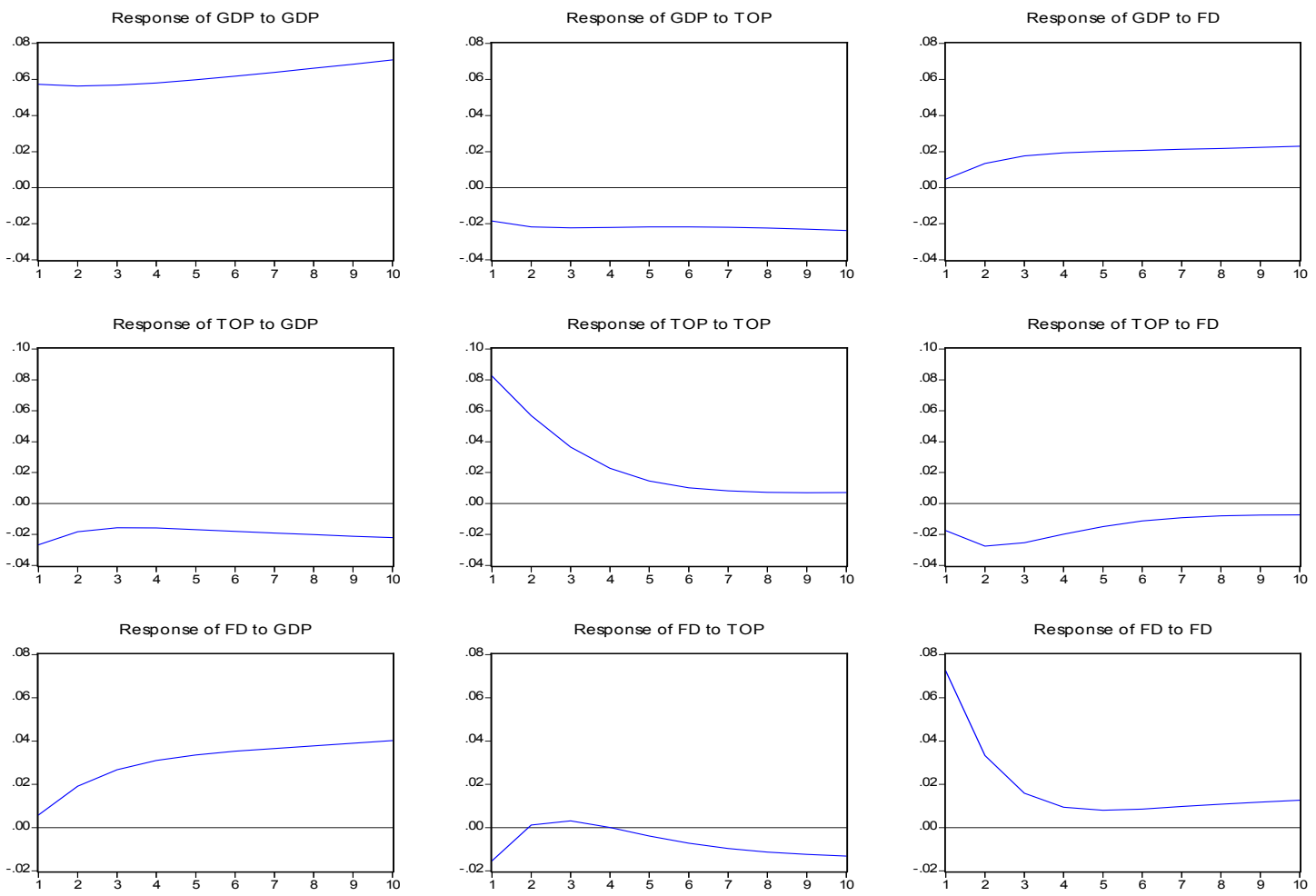

Figure 1. Impulse response function

On the other hand, economic growth contributes positively to financial development till 10th time horizon. The response of trade openness is negative due to forecast error stemming in economic growth.

Tables 8 to 10 show the variance decomposition in calculating and analyzing the influence of random shocks of macroeconomic variables upon the NPF of Islamic banks. As can be seen, there are two variables that influence NPF rate. These variables are exchange rate and the economic growth.

Table 8. Variance decomposition of GDP

\begin{tabular}{ccccc}
\hline Period & S.E. & GDP & TOP & FD \\
\hline 1 & 0.057262 & 100 & 0 & 0 \\
2 & 0.080868 & 98.73757 & 0.215661 & 1.046771 \\
3 & 0.0997 & 97.46108 & 0.314462 & 2.224454 \\
4 & 0.116328 & 96.54356 & 0.317003 & 3.139435 \\
5 & 0.131717 & 95.93816 & 0.284103 & 3.777741 \\
6 & 0.146356 & 95.54418 & 0.245635 & 4.21018 \\
7 & 0.160531 & 95.28337 & 0.211292 & 4.505339 \\
8 & 0.174422 & 95.10475 & 0.182814 & 4.712439 \\
9 & 0.188153 & 94.97707 & 0.159602 & 4.86333 \\
10 & 0.201817 & 94.88161 & 0.140639 & 4.977751 \\
\hline
\end{tabular}

Table 8 shows the variance decomposition in calculating and analyzing the influence of random shocks of GDP upon itself and TOP and FD. The results reveal that a 94.88 percent portion of economic growth is contributed by its own innovative shocks and one standard deviation shock in financial development explains economic growth by 4.98 percent while the support of trade openness to economic growth is minimal i.e. 0.14 percent. 
Table 9. Variance decomposition of TOP

\begin{tabular}{ccccc}
\hline Period & S.E. & GDP & TOP & FD \\
\hline 1 & 0.082351 & 10.47972 & 89.52028 & 0.000000 \\
2 & 0.101305 & 10.15717 & 87.38026 & 2.462567 \\
3 & 0.109236 & 10.80150 & 84.38756 & 4.810945 \\
4 & 0.112985 & 12.04613 & 81.63169 & 6.322175 \\
5 & 0.115253 & 13.69753 & 79.16552 & 7.136953 \\
6 & 0.117100 & 15.63100 & 76.84606 & 7.522936 \\
7 & 0.118898 & 17.75490 & 74.56795 & 7.677144 \\
8 & 0.120763 & 20.00073 & 72.28600 & 7.713267 \\
9 & 0.122729 & 22.31912 & 69.98983 & 7.691054 \\
10 & 0.124803 & 24.67606 & 67.68287 & 7.641066 \\
\hline
\end{tabular}

As indicated in Table 9, trade openness is explained by economic growth to the extent of 24.68 percent. On the other hand, the contribution of financial development to explain trade openness is 7.64 percent. The fluctuation of TOP is accounted by TOP itself with 67.68 percent.

Table 10. Variance decomposition of FD

\begin{tabular}{ccccc}
\hline Period & S.E. & GDP & TOP & FD \\
\hline 1 & 0.072407 & 0.662359 & 3.842368 & 95.49527 \\
2 & 0.082646 & 5.852876 & 3.837659 & 90.30947 \\
3 & 0.089289 & 13.97428 & 5.235517 & 80.79020 \\
4 & 0.095576 & 22.74543 & 5.821748 & 71.43282 \\
5 & 0.101805 & 30.92680 & 5.659983 & 63.41322 \\
6 & 0.108037 & 38.10921 & 5.196042 & 56.69475 \\
7 & 0.114318 & 44.26820 & 4.682737 & 51.04907 \\
8 & 0.120677 & 49.52450 & 4.209126 & 46.26638 \\
9 & 0.127131 & 54.03138 & 3.792935 & 42.17569 \\
10 & 0.133692 & 57.92837 & 3.429973 & 38.64166 \\
\hline
\end{tabular}

The share of economic growth to financial development is approximately 57.93 percent and 3.43 percent due to trade openness. The innovative shocks stem in financial development explain itself by 38.64 percent.

\section{Conclusion}

Financial development and trade openness are generally considered important factors for economic growth. However, the existing literature provide us with inconclusive evidence due to country specific factors and different methods utilized by the studies. Hence, country specific study supported by well-developed method is worthy to pursue.

In this paper, we use time series econometric techniques to investigate the direction of causality between trade openness, financial development and economic growth for the Kingdom Bahrain over the period from1980 until 2012. We utilized the VECM Granger causality approach to examine the long and short-run relationship between the variables.

The findings of this study can be summarized as follows: First, the results show one-way causality from trade openness and financial development to real GDP growth in Bahrain. Financial development enhances domestic production by boosting investment activities and hence raises economic growth. Second, financial development Granger causes economic growth supporting the supply-side hypothesis. Third, trade openness is Granger causes by financial development.

The empirical results of this study suggest the following policy treatments: Bahrain should continue to patronize the development of its financial sector. This sector should be as open, competitive and efficient as possible. Attempts must be taken for more transparency and acceleration of the development process. Furthermore, the experiences from other countries prove that the impact of financial development on economic growth comes mainly from increasing investment efficiency rather than investment volume.

Intensive efforts must be made to speed up and increase the Kingdom foreign trade. Bahrain contribution to 
world trade must be increased to expedite its economic growth. Import of capital goods is more desirable to boost production capacity and ultimately increase and diversify export.

\section{References}

Aghion, P., Howitt, P., \& Mayer-Foulkes, D. (2005). The effect of financial development on convergence: Theory and evidence. Quarterly Journal of Economics, 120, 173-222. http://dx.doi.org/10.1162/qjec.2005.120.1.173

Amable, B., \& Chatelain, J. B. (2001). Can financial infrastructures foster economic development? Journal of Development Economics, 64(2), 481-498. http://dx.doi.org/10.1016/S0304-3878(00)00147-4

Beck, T. (2011). The role of finance in economic development: Benefits, risks, and politics. Discussion Paper, 2011-141. Tilburg University, Center for Economic Research.

Beck, T. (2013). Finance, growth and fragility: The role of government. CEPR Discussion Paper 9597, C.E.P.R. Discussion Papers.

Beck, T., Demirgüç-Kunt, A., Laeven, L., \& Levine, R. (2008). Finance, firm size, and growth. Journal of Money, Banking and Credit, 40(7), 1379-1405. http://dx.doi.org/10.1111/j.1538-4616.2008.00164.x

Beck, T., Levine, R., \& Loayza, N. (2000). Financial intermediation and growth: Causality and causes. Journal of Monetary Economics, 46, 31-77. http://dx.doi.org/10.1016/S0304-3932(00)00017-9

Bencivenga, V. R., \& Smith, B. D. (1991). Financial intermediation and endogenous growth. The Review of Economic Studies, 58(2), 195-209. http://dx.doi.org/10.2307/2297964

Bencivenga, V., Smith, B., \& Starr, R. (1995). Transaction costs, technological choice and endogenous growth. Journal of Economic Theory, 67(1), 153-177. http://dx.doi.org/10.1006/jeth.1995.1069

Benhabib, J., \& Spiegel, M. M. (2000). The role of financial development in growth and investment. Journal of Economic Growth, 5(4), 341-360. http://dx.doi.org/10.1023/A:1026599402490

Calderon, C., \& Liu, L. (2003). The direction of causality between financial development and economic growth. Journal of Development Economics, 72(1), 321-334. http://dx.doi.org/10.1016/S0304-3878(03)00079-8

Central Bank of Bahrain (CBB). (2011). Fact Sheet, April.

Chimobi, O. P. (2010). The causal relationship among financial development, trade openness and economic growth in Nigeria. International Journal of Economics and Finance, 2(2), 137-147. http://dx.doi.org/10.5539/ijef.v2n2p137

Dabos, M., \& Williams, T. (2009). A reevaluation of the impact of financial development on economic growth and its sources by regions. MPRA Paper 27297, University Library of Munich, Germany.

DeJong, D. N., Nankervis, J. C., \& Savin, N. E. (1992). Integration versus trend stationarity in time series. Econometrica, 60(2), 423-433. http://dx.doi.org/10.2307/2951602

Dickey, F., \& Fuller, W. A. (1981). Likelihood ratio statistics for autoregressive time series with a unit root. Econometrica, 49(4), 1057-1072. http://dx.doi.org/10.2307/1912517

Dollar, D. (1992). Outward-oriented developing economies really do grow more rapidly: Evidence from 95LDCs, 1976-1985. Economic Development and Cultural Change, 40(3), 523-544. http://dx.doi.org/10.1086/451959

Dollar, D., \& Kraay, A. (2001). Trade, growth, and poverty. World Bank Policy Research Working Paper No. 2615.

Dollar, D., \& Kraay, A. (2004). Trade, growth, and poverty. The Economic Journal, 114(493), $22-49$. http://dx.doi.org/10.1111/j.0013-0133.2004.00186.x

Economic Intelligence Unit. (2011). Citi Private Bank: Quadrant politics matters. note, 14, February (2011).

Edwards, S. (1997). Openness, productivity and growth: What do we really know? NBER Working Papers, No. 5978. Cambridge: NBER.

Ehinomen, C., \& Da'silva, D. (2014). Impact of trade openness on the output growth in the Nigerian economy. British Journal of Economics, Management \& Trade, 4(5), 755-768. http://dx.doi.org/10.9734/BJEMT/2014/6682

Eicher, T. (1999). Trade, development and converging growth rates: Dynamic gains from trade reconsidered. Journal of International Economics, 48(1), 179-198. http://dx.doi.org/10.1016/S0022-1996(98)00028-2 
Enders, W. (2003). Applied econometric time series. Hoboken, NJ: Wiley.

Foster, N. (2008). The impact of trade liberalization on economic growth: Evidence from a quintile regression. Kyklos, 61(4), 543-567. http://dx.doi.org/10.1111/j.1467-6435.2008.00417.x

Frankel, J., \& Romer, D. (1999). Does trade cause growth? American Economic Review, 89(3), $379-399$. http://dx.doi.org/10.1257/aer.89.3.379

Goldsmith, R. W. (1969). Financial structure and development. New Haven, Conn.: Yale University Press.

Grossman, G. (1992). Imperfect competition and international trade. Cambridge, MA: The MIT Press.

Grossman, G., \& Helpman, E. (1991a). Innovation and growth in the global economy. MIT Press, Cambridge, MA.

Grossman, G., \& Helpman, E. (1991b). Quality ladders in the theory of growth. Review of Economic Studies, LVIII, 43-61. http://dx.doi.org/10.2307/2298044

Hall, S. G., \& Henry, S. S. B. (1989). Macroeconomic modelling. Amsterdam, The Netherlands: Elsevier Science Publishers.

Harris, R., \& Sollis, R. (2003). Applied time series modelling and forecasting. John Wiley, West Sussex.

Harrison, A. (1996). Openness and growth: A time-series, cross-country analysis for developing countries. Journal of Development Economics, 48(2), 419-447. http://dx.doi.org/10.1016/0304-3878(95)00042-9

Islam, F., Shahbaz, M., \& Rahman, M. M. (2014). Trade openness, financial development, energy use and economic growth in Australia: Evidence on long run relation with structural breaks. MPRA Paper No. 52546.

Jin, J. C. (2003). Openness and growth in North Korea: Evidence from time-series data. Review of International Economics, 11(1), 18-27. http://dx.doi.org/10.1111/1467-9396.00365

Johansen, S., \& Juselius, K. (1990). Maximum likelihood estimation and inference on cointegration with applications to money demand. Oxford Bulletin of Economics and Statistics, 52(2), 169-210. http://dx.doi.org/10.1111/j.1468-0084.1990.mp52002003.x

Kar, M., Peker, O., \& Kaplan, M. (2008). Trade liberalization, financial development and economic growth in the long term: The case of Turkey. South East European Journal of Economics and Business, 3(2), 25-38. http://dx.doi.org/10.2478/v10033-008-0012-x

Khan. M. A., \& Qayyum, A. (2007). Trade liberalization, financial development and economic growth. PIDE Working Papers, No. 19.

King, R. G., \& Levine, R. (1993a). Finance and growth: Schumpeter might be right. Quarterly Journal of Economics, 108(3), 717-737. http://dx.doi.org/10.2307/2118406

King, R. G., \& Levine, R. (1993b). Finance, entrepreneurship, and growth: Theory and evidence. Journal of Monetary Economics, 32(3), 513-542. http://dx.doi.org/10.1016/0304-3932(93)90028-E

Kletzer, K., \& Bardhan, P. (1987). Credit markets and patterns of international trade. Journal of Development Economics, 27(1-2), 57-70. http://dx.doi.org/10.1016/0304-3878(87)90006-X

Kurt, S., \& Berber, M. (2008). Openness in Turkey and economic growth. Ataturk University Economic and Administrative Journal, 22(2), 57-79.

Lee, H. Y., Ricci, L. A., \& Rigobon, R. (2004). Once again, is openness good for growth? NBER Working Papers, No. 9578. Cambridge: NBER. http://dx.doi.org/10.3386/w10749

Lee, J. (1993). International trade, distortions, and long-run economic growth. International Monetary Fund Staff Papers, 40(2), 299-328. http://dx.doi.org/10.2307/3867316

Levine, R. (1997). Financial development and economic growth: Views and agenda. Journal of Economic Literature, 35(2), 688-726.

Levine, R. (2005). Finance and growth: Theory and evidence. Handbook of Economic Growth. In P. Aghion \& S. Durlauf (Eds.), Handbook of Economic Growth (1 ${ }^{\text {st }}$, ed., Vol. 1, Cha. 12, pp. 865-934). Elsevier. http://dx.doi.org/10.1016/S1574-0684(05)01012-9

Levine, R., \& Zervos, S. (1998). Stock markets, banks, and economic growth. The American Economic Review, $88(3), 537-558$. 
Liang, Q., \& Teng, J. Z. (2006). Financial development and economic growth: Evidence from China. China Economic Review, 17(4), 395-411. http://dx.doi.org/10.1016/j.chieco.2005.09.003

Liu, X., \& Shu, C. (2002). The relationship between financial development and economic growth: Evidence from China. Studies in Economics and Finance, 20(1), 76-84. http://dx.doi.org/10.1108/eb028760

Loayza, N., Fajnzylber, P., \& Calderon, C. (2005). Economic growth in Latin America and the Caribbean: Stylized facts, explanations, and forecasts. The World Bank, Washington, DC. http://dx.doi.org/10.1596/0-8213-6091-4

Lucas, R. E. (1988). On the mechanics of economic development. Journal of Monetary Economics, 22(1), 3-42. http://dx.doi.org/10.1016/0304-3932(88)90168-7

Masoud, N., \& Hardaker, G. (2012). The impact of financial development on economic growth: Empirical analysis of emerging market countries. Studies in Economics and Finance, 29(3) 148-173. http://dx.doi.org/10.1108/10867371211246830

Michalopoulos, S., Laeven, L \& Levine, R. (2009). Financial innovation and endogenous growth. NBER Working Papers. No. 15356. Cambridge: NBER. http://dx.doi.org/10.3386/w15356

Oguzoglu, U., \& Stengos, T. (2011). Can dynamic panels explain finance-growth link? An application to empirical likelihood. Review of Economic Analysis, 3(2), 129-148.

Oh, W., \& Lee, K. (2004). Causal relationship between energy consumption and GDP revisited: The case of Korea 1970-1999. Energy Economics, 26(1), 51-59. http://dx.doi.org/10.1016/S0140-9883(03)00030-6

Omisakin, O., Oluwatosin, A., \& Ayoola, O. (2009). Foreign direct investment, trade openness and growth in Nigeria. Journal of Economic Theory, 3(2), 13-18.

Onayemi, S. O. (2013). Output growth, economic openness and financial deepening in Nigeria: A structural differential and causality analyses. European Journal of Humanities and Social Sciences, 26(1), 13811395 .

Özyildirim, S., \& Önder, Z. (2008). Banking activities and local output growth. Regional Studies, 42, $229-244$. http://dx.doi.org/10.1080/00343400601142829

Panizza, U. (2013). Financial development and economic growth, known knowns, known unknowns, and unknown unknowns. Paper prepared for the 2013 AFD-BMZ-EUDN annual conference on development (Berlin, December 11, 2013).

Pasali, S. (2013). Where is the cheese? Synthesizing a giant literature on causes and consequences of financial sector development. Policy Research Working Paper Series No. 6655, the World Bank. http://dx.doi.org/10.1596/1813-9450-6655

Phillips, P., \& Perron, P. (1988). Testing for unit root in time series regression. Biometrika, 75(2), 335-346. http://dx.doi.org/10.2307/2336182

Polat, A., Ijaz, M. S., Rehman, U., \& Satti, S. L. (2013). Revisiting linkages between financial development, trade openness and economic growth in South Africa: Fresh evidence from combined cointegration test. MPRA Paper No. 51724.

Pradhan, R. P. (2011). Finance development, growth, and inflation: The trilateral analysis in India. Journal of Economic and Social Research, 13(2), 45-59.

Rajan, R., \& Zingales, L. (1998). Financial dependence and growth. American Economic Review, 88(3), 559586.

Rebelo, S. (1991). Long-run policy analysis and long-run growth. Journal of Political Economy, 99(3), 500-521. http://dx.doi.org/10.1086/261764

Rivera-Batiz, L., \& Romer, P. (1991). Economic integration and endogenous growth. Quarterly Journal of Economics, 106(2), 531-566. http://dx.doi.org/10.2307/2937946

Rodríguez, F., \& Rodrik, D. (1999). Trade policy and economic growth: A skeptic's guide to the cross-national evidence. NBER Working Papers, 7081. Cambridge: NBER.

Romer, P. M. (1986). Increasing returns and long-run growth. Journal of Political Economy, 94(5), $1002-1037$. http://dx.doi.org/10.1086/261420

Romer, P. M. (1990). Endogenous technological change. The Journal of Political Economy, 98(5), S71-S102. 
http://dx.doi.org/10.1086/261725

Rousseau, P. L., \& Wachtel, P. (1998). Financial intermediation and economic performance: Historical evidence from five industrialized countries. Journal of Money, Credit, and Banking, 30(4), 657-678. http://dx.doi.org/10.2307/2601123

Sachs, J. D., \& Warner, A. M. (1995). Natural resource abundance and economic growth. NBER Working Papers, No. 5398. Cambridge: NBER. http://dx.doi.org/10.3386/w5398

Shahbaz, M., Hye, Q. M. A., Tiwari, A. K., \& Leitão, N. C. (2013). Economic growth, energy consumption, financial development, international trade and $\mathrm{CO} 2$ emissions in Indonesia. Renewable and Sustainable Energy Reviews, 25, 109-121. http://dx.doi.org/10.1016/j.rser.2013.04.009

Shahbaz, M., Khan, S., \& Tahir, M. I. (2013). The dynamic link between energy consumption, economic growth, financial development and trade in China: Fresh evidence from multivariate framework analysis. Energy Economics, 40(11), 8-21. http://dx.doi.org/10.1016/j.eneco.2013.06.006

Shan, J., \& Morris, A. (2002). Does financial development lead economic growth: An egg-and-chicken problem. Review of International Economics, 9(3), 443-454. http://dx.doi.org/10.1111/1467-9396.00291

Srinivasan, T. N., \& Bhagwati, J. (2001). Outward-orientation and development: Are revisionists right? In D. Lal \& R. H. Snape (Eds.), Trade, Development and Political Economy: Essays in Honour of Anne O. Krueger. New York: Palgrave.

Tash, M. N. S., \& Sheidaei, Z. (2012). Trade liberalization, financial development and economic growth in the long term: The case of Iran. Business and Economic Horizons, 8(2), 33-45. http://dx.doi.org/10.15208/beh.2012.9

Tiwari, A. K. (2011). Financial development, CO2 emission and economic growth: Evidence from India. Journal of International Business and Economy, 12(1), 85-122.

Utkulu, U., \& Kahyaoğlu, H. (2005). How did the trade and financial openness in Turkey affected the growth? Turkish Economy Institution Argument Text 13, Web. Retrieved from http://www.tek.org.tr/dosyalar/Utkulu-2005

Wacziarg, R. (1998). Measuring the dynamic gains from trade. Working Paper. Graduate School of Business, Stanford University.

World Bank. (1989). World Development Report 1989. New York: Oxford University Press.

Xiaohui, L., \& Chang, S. (2002). The relationship between financial development and economic growth: Evidence from China. Studies in Economics and Finance, 20(1), 76-84. http://dx.doi.org/10.1108/eb028760

Yaprakli, S. (2007). The relationship between trade and financial openness and economic growth: An application on Turkey. Econometric and Statistics Journal, 5, 68-89.

Yavari, K., \& Mohseni, R. (2012). Trade liberalization and economic growth: A case study of Iran. Journal of Economic Policy Reform, 15(1), 13-23. http://dx.doi.org/10.1080/17487870.2011.642579

Yazdi, S. K., \& Shakouri, B. (2014). The econometric model for CO2 emissions, energy consumption, economic growth, foreign trade, financial development and urbanization of Iran. Journal of Environmental Research and Development, 8(3A), 828-840.

Young, A. (1991). Learning by doing and the dynamic effects of international trade. The Quarterly Journal of Economics, 106(2), 369-405. http://dx.doi.org/10.2307/2937942

\section{Copyrights}

Copyright for this article is retained by the author(s), with first publication rights granted to the journal.

This is an open-access article distributed under the terms and conditions of the Creative Commons Attribution license (http://creativecommons.org/licenses/by/3.0/). 